\title{
IMPORTANCE OF PROMOTING SALES IN ELECTRONIC SHOPS FOR B2C CUSTOMERS
}

\author{
Viktor Janouch $^{1}$, Kateřina Knápková ${ }^{2}$ \\ ${ }^{1}$ Univerzita Pardubice, Fakulta chemicko-technologická, Studentská 95, 53210 Pardubice \\ Email: viktor.janouch@upce.cz. \\ ${ }^{2}$ Univerzita Pardubice, Fakulta chemicko-technologická, Studentská 95, 53210 Pardubice \\ Email: katos.knapy@seznam.cz
}

\begin{abstract}
The article deals with sales promotion in electronic shops. As one of the methods of marketing communications, sales promotion is a dynamically developing area. For e-shops, it is a key part of their marketing communications in an environment of increasing competition, where the volume of purchases over the Internet may be increasing, but at the same time, however, this fact is attracting more and more businesses and individuals to establish e-shops. Moreover, the development of information and mobile technologies and changes in customer behavior makes the forms of sales promotion acquire new forms. This situation has not been satisfactorily mapped in the literature yet. The article therefore aims to provide a comprehensive overview of forms of sales promotion, usable in electronic shops, and thereby create a starting point for the subsequent implementation of qualitative and quantitative researches aimed at increasing the effectiveness of sales promotion.
\end{abstract}

Keywords: communications, Internet, marketing, sales promotion.

JEL classification: M31

Doručeno redakci: 17.10.2012; Recenzováno: 2.4.2013; 19.3.2013; Schváleno k publikování: 11.9.2013

\section{Introduction}

Marketing communication on the Internet, including sales promotion, has recorded a dynamic development in recent years through continuous expansion and improvement of information and communication technologies. This is, however, related to a gradual change in consumer behavior and a rapid onset of online shopping. Thanks to new possibilities of online communication, companies can better serve their customers. Using other tools of marketing communication, a firm can customize a product to requirements, preferences and wishes of customers and provide a greater value to the customer (Lošt'áková, 2009), and to some extent also in the B2C area, thereby achieving both higher sales and profits. In the case of electronic transactions, within marketing communications, firms make use especially of various forms of sales promotion.

Although online marketing communication is considered very beneficial, it also has its drawbacks and disadvantages. The rapid development of information technology may thus easily turn into a disadvantage because customers use different devices and applications that may prevent or impede the use of Internet services including e-commerce. Electronic shops are therefore trying to make their customers use various devices (PC, mobile, tablet) while testing their websites for access via different types of browsers.

Thus, if the visitor has already entered the site successfully, the ultimate goal is to make the visitor stay on the website and then buy. Consequently, it is necessary to provide the customer with a motivation so that it was worth it for them to go back some time later and do the shopping again. This can be greatly assisted with a combination of different forms of sales promotion. However, an optimal combination cannot be determined due to the fact that each e-shop is different not only in terms of range of goods, but also in terms of target segments. 
Moreover, even within the competitive e-commerce shops aimed at the same segment there is considerable differentiation in the behavioural sense.

The constant changes can thus be the reason why authors do not pay sufficient attention to sales promotion issues in e-shops. Therefore, we focused on providing an overview of forms of sales promotion, possibilities to measure its effectiveness and qualitative research on the use of different forms in practice.

\section{Marketing Communication on the Internet}

Marketing communication is one of the four components of the classic marketing mix. On the Internet, however, the methods of marketing communication are rather different. It is not only about the aforementioned technical aspect, but also the different content of the communication. Quite a specific example is e-mailing, PPC advertising, the use of social media, as well as sales promotion with the possibilities of formation of sets, cross-selling, or affiliate (or partner) programs.

Sales promotion is a technique of marketing communication that affects the customer by certain stimuli, thereby initiating an interest in selling products. Sales promotion aims to encourage, facilitate and encourage the purchasing decisions of customers and also to make them decide to buy immediately or, more precisely, to provide favourable conditions for repeat purchase (Foret, 2006). There are various forms of sales promotion that are similar both with the classic forms of sales support as well as on the Internet. However, some forms appear only in the online environment. An important task of internet sales promotion is to increase customer loyalty to a given e-shop, while it is clear that customer loyalty to one eshop is difficult to solve sustain. Differences in e-commerce offerings are often negligible and the customer thus finds his/her way back to the same e-shop only in case of other incentives than just price, or discounts.

Many authors, for example De Pelsmacker (2003), Foret (2006) provide an overview of the techniques and forms of marketing communication, but they devote themselves to the Internet only marginally. De Pelsmacker (2003), however, points to the importance of promoting sales by claiming that the decision to purchase is increasingly impulsive and most of these decisions occur as late as at the point of purchase. On the Internet it is therefore typically eshop. At the same time, he divides the forms of sales promotion into customer sales promotion (financial incentives, competitions and lotteries, product support) and business support (margins, volume discounts, promotional benefits, etc.). Kotler (2007) divides sales promotion in consumer sales promotion (samples, coupons, discounts, loyalty programs, etc.), retailer sales promotion (free goods, discounts, etc.) and sales promotion for the company and its sales force (fairs, conferences, and others), while including the marketing communication on the Internet as a whole in the direct marketing. In contrast, Foret (2006) distinguishes direct and indirect forms of sales promotion where, in his opinion, the direct sales promotion gives customers an immediate benefit (discount, action set), while indirect forms of sales promotion have a longer effect (loyalty programs). Marketing communication on the Internet is discussed in detail also by Frey (2008) who, however, describes only a single area of sales promotion, and that is loyalty programs. A more detailed overview is provided by Janouch (2010) firstly by dividing the methods of marketing communication into advertising, sales promotion, events, public relations and direct marketing, and then by analyzing in detail various methods of marketing communication on the Internet, dividing the forms of sales promotion into incentives to buy (competitions, discounts, goods samples, coupons, etc.), affiliate programs and loyalty programs. We believe that this division corresponds best to the 
nature of individual forms of sales promotion, but it is also necessary to take into account the differences in the $\mathrm{B} 2 \mathrm{C}$ and $\mathrm{B} 2 \mathrm{~B}$ areas.

\section{Forms of Sales Promotion on the Internet in the B2C Field}

According to Hesková (2009) on the B2C markets, sales promotion serves to increase sales and market share, gives customers an opportunity to try new products, acquires customers of competitors, maintains and motivates loyal clients. Forms of sales promotion, however, are more effective in the B2B area, because the supply and sale of products is designed for relatively small groups in order to obtain special information ${ }^{1}$. Most electronic shops sell to end customers, and Although there are different forms of sales promotion, there is no assumption of the use of all forms simultaneously (Janouch, 2011). Sales promotion has to be limited in time and space and cause an immediate purchase reaction (De Pelsmacker, 2003). All forms of promotion are provided immediately upon purchase, but some are short-term, for example limited in time for the transaction or for a certain number of days, others have impact in a longer term. It is therefore appropriate to further divide the forms of sales promotion, as already mentioned, into incentives for purchase, loyalty programs and affiliate programs. Here, in particular the temporal aspect is taken into account, but this is not entirely true for affiliate programs.

\subsection{Incentives to Purchase}

Incentives to purchase usually include such forms of sales promotion that can be used immediately during the purchasing process. Due to the technical possibilities of the Internet, incentives to purchase can be presented to customers both in a differentiated way, based on the ongoing purchase according to what shoppers have in their electronic baskets or what pages they are just browsing, and also variously combine them. Technically, you can also set incentives to certain hours or days, or depending on which web browser visitors to the shop use, from which country or region they come and according to a number of other parameters, and with an additional option of interactivity. E-shops thus partly adopted forms of incentives to purchase from the offline environment and also came with quite specific forms and solutions. Correct setting of the mix of incentives depends on corporate resources and conditions, target market, product characteristics and feasibility of different forms (Pride, 2012).

\section{Samples}

A sample allows testing small quantities of a product. Thereby, dealers want to familiarize customers with new, similar or even completely different products. It is one of the most costly forms of sales promotion (Pride, 2012). This form was previously specific rather for brickand-mortar shops, but today samples are used in many electronic stores. Here, they are not provided due to the cost of delivery separately, but with the purchase made. E-shops usually provide samples of very different products than the customer has purchased, thus wanting to attract attention and make customers return to the e-shop. Another option is sending a sample of the same kind, but of other brands or variants, or possibly offering intangible product samples, typically demo software (Janouch, 2010).

\section{Coupons}

Customers have a very positive opinion of coupons and enjoy using them (Janouch, 2010). Lamb (2011) states that coupons are up to 10 times more effective in the online environment than in the offline environment, being used by almost $50 \%$ of e-commerce customers who

\footnotetext{
${ }^{1}$ BROŽ, František: B2B sales promotion. Marketing Journal [on-line] [2011-11-18] Available from < http://www.m-journal.cz/cs/podpora-prodeje/b2b-sales-promotion_s394x429.html>.
} 
have them at their disposal. Therefore, they belong to very good sales promotion tools; we find them in almost every e-shop and they are also used as an effective form of sales promotion within loyalty programs.

Coupons may offer a discount on the price of goods purchased, but also an opportunity to buy goods otherwise unavailable. The customer may obtain a coupon after a purchase made, but eshops also provide anonymous coupons. Such coupons may be found on the Internet in, for example, advertising (PPC), public relations (articles) or direct marketing (promo e-mail). They are then used for shopping in the e-shop. Often used are also coupons known as gift vouchers. Typically, they do not offer a discount, but purchase of goods with a value specified on the voucher. This gives companies an opportunity to reach another group of customers still unaware of the existence of the e-shop or a particular product.

\section{Competitions, Lotteries, Surveys}

The principle of all these incentives to purchase is that customers can receive a product for free. Competitions, lotteries and surveys are enjoyed by a large number of buyers in electronic shops. For e-shops, this means a higher number of visits and thus influx of potential customers. Many retailers therefore try to have at least one of these incentives in their eshops. Competitions, lotteries or surveys, however, have drawbacks in that in many cases they may ensure increase in sales, but this does not have to be followed by an increase in profit (Janouch, 2010). This is due to the need to spend significant costs of prizes at times. On the customer side, participation may then be influenced by the fact that it is often not products for free what is provided as rewards, but only discounts or additional services. The customer may thus have some psychological problems with participation in a competition, lottery or survey that does not ultimately offer a product for free.

With competitions and lotteries, legislative issues may occur. Competitions and lotteries are regulated by law; however, in the case of lotteries much stricter conditions are set.

\section{Discounts}

Shoppers encounter constantly discounts on the Internet. Customers in many countries are very sensitive to the discount, particularly with certain types of goods (food, consumer electronics). Therefore, a success has been reported of discount aggregators (Groupon, Slevomat). Discounts can be sorted by various criteria: quantity discounts, financial, temporary (to a date, while supplies last, within a certain time) or permanent discounts. However, discounts affect only some customers and they are not the main reason for them to buy. Discount should be only of a short-term nature, because otherwise it loses its uniqueness and effectiveness. The customer ceases to perceive goods with a permanent discount as discounted. Limited duration discounts generally increase revenues (Shimp, 2010).

Lamb (2011) equate discount with coupons, but, like Pride (2012) or Shimp (2010), we believe that due to the wider possibilities of using coupons these two types of incentives to purchase need to be distinguish.

\section{Sets of Products (Action Sets)}

A set of several products placed in one package sold at a discount is often called an action set. In essence, it is a discount again. This form of sales usually brings an increase in sales revenue while naturally reducing profits. This form of sales promotion can also include discounted packages (multiple pieces of the same product in the same package). 


\section{Cross-selling}

The aim of cross-selling is to get the customer to purchase an additional product or service. Typically, it's an accessory to the selected product or service associated with purchasing (installation, etc.). Additional items should be related to the products that the customer has already bought and the price of accessory goods should not significantly affect the price of the sold product (Janouch, 2010). Technical possibilities of e-commerce have contributed to a significant expansion of this form of sales promotion. It is also easy for e-shops to change the offer of accessory product range very quickly, often even during the purchasing process.

\section{Up-selling}

The role of up-selling is to get the customer to buy a product in a better variant than the one he/she has chosen. Products in a higher variant usually also have a higher price, which increases sales revenues and profit. A higher version of the product is usually also characterized by better equipment, additional services or guarantee or even a premium paint. The product price in a better variant should not be much higher, because then the customers let themselves easily entice to purchase better alternatives of this product, otherwise they already consider it a different kind of product.

\section{Product Comparison}

The advantage of e-commerce is the possibility of comparing goods. It is an easy and quick help in making purchasing decisions. The customer has the possibility to compare, for example, the same product from several manufacturers or, conversely, different products from the same manufacturer, or choose a combination of both approaches. E-shops create overviews of products compared only for those goods that can be compared. This ensures that the customer sees in the table each property compared in a row over all the selected products. Increasingly, also evaluation of their users is appearing with the products compared, whether in the form of the points awarded (stars, etc.) or verbal evaluation. To some extent, comparing products can be paralleled to up-selling.

\section{Free Shipping and Postage}

Free shipping and postage is a significant form of sales promotion on the Internet, leading to increased sales and purchase volume and therefore it is often used by retailers. Delivery of goods free of charge is what the success of major e-shops such as Amazon.com has been, besides other things, accounted for (Pride, 2012). In most e-shops, free delivery is subject to purchase over a certain amount. The trend in recent years, particularly in the U.S., is then free delivery of any goods without this condition. Here, the question is what is better for retailers. On the one hand, surely every customer will be satisfied with the free delivery of goods; on the other hand a certain threshold to qualify for free delivery motivates more purchases. We believe that the answer to this question will require a more extensive study over a longer period of time.

\section{Extension of the Statutory Time Limits}

The warranty for the goods is specified in law. In many countries, the distinction is made between purchasing for business purposes and purchasing by a citizen. Also, the possibility of returning the goods without giving any reason is legislatively modified and may vary greatly between countries. While statutory time limits must be complied with by all retailers, some accommodate customers by voluntarily lengthening these time limits, which appears with certain goods as a relatively strong incentive to purchase. 


\subsection{Loyalty Programs}

Loyalty programs focus on providing benefits for loyal customers when buying products, i.e. for those who buy repeatedly. The role of loyalty programs is to create customers devoted to a brand (Shimp, 2010). A returning customer brings the firm not only a higher profit and increase in revenues, but he/she also provides feedback on the course of the purchase and products as such. It is very likely that he/she will pass references to his/her neighbourhood. Companies therefore use different ways to attract customers back to the e-shop. The aim is to communicate directly with the customer. For this purpose, the most used is e-mailing, sometimes also telemarketing.

Loyalty programs in e-commerce include various incentives to buy, but they are more sophisticated in order to attract customers to use them. They are almost exclusively for registered customers only. The way to implement loyalty programs may be a in the form of:

- bonuses - the customer collects points that can be applied to repeat purchase,

- coupons - for discounts or specific goods,

- discounts on the next purchase - with every repeat purchase, quantity or volume discount is offered,

- customer club membership - the customer receives a card with which to buy selected goods at a discount,

- goods or services free of charge - the customer receives the goods or services for free on the next purchase.

Loyalty programs may not appeal to all customers. Many of them buy exclusively without registration while others may have some concerns about the misuse of data for commercial communications both by the firm itself and third parties. Besides, the customer may not be interested in the rewards offered at all. Overall, loyalty programs have recently attracted fewer customers (Lamb, 2012).

\subsection{Affiliate Programs}

Affiliate program is a specific way of sales promotion on the Internet based on the sale of products through a third party that owns the website, i.e. on cooperation with the sales agent. The reward for the agent is either a commission for a business realized, or a fixed payment for customer acquisition, sometimes just for bringing a mere visitor to the e-shop. In this case, it is not just about selling products, but also about advertising (mostly in the form of banner). Affiliate program can thus combine the advantages of the both methods of marketing communication - sales promotion and advertising. The condition for the partner to the e-shop is to have a website with related topics and, at the same time, the commission (payment) for the agent needs to be sufficiently high. Otherwise, this method of sale is only marginally effective.

\section{Effectiveness of Sales Promotion in E-shops}

The origins of Internet commerce fall back to the year 1992, but e-commerce as we know it today emerged as late as in the years 1994 and 1995. The development of e-commerce was significantly supported by the possibility to pay online, i.e. using credit cards, and later by other methods (PayPal). That was one of the reasons for massive expansion of e-shops in the U.S. and, on the contrary, lagging of Europe where distrust of payment with cards was initially significant and in some countries still is. Other reasons for differences in the rate of development of e-commerce are to be found in the technical equipment. Other reasons for initially slow onset of online shopping were concern about the safety of customer data and 
distrust as to whether the products ordered would actually be delivered. In the last few years, however, all of the above reasons practically ceased to exist, and electronic commerce records a significant increase.

As one of the main reasons for the increase, we can mention the professionalism of some major online retailers. With these traders, a short delivery time is commonplace, and so is complete information on products, clear technical information, easy return merchandise authorization, warranty and post-warranty service or the option of returning the goods within the statutory period and even beyond.

The rapid development of e-commerce allows introducing further features and options that we call customization and personalization. These features give a possibility to prepare an offer for a particular user based on his/her personal preferences and provide him/her with special services, aiming to create loyalty and customer satisfaction.

An important aspect of e-commerce is the actual creation of e-shops. It is necessary to remember the basic concepts such as accessibility and usability of applications. Application accessibility enables barrier-free access to the website (to the e-shop), especially for customers with hearing, visual or mobility impairment. Accessibility rules are defined in different countries according to local laws. Unlike accessibility, the concept of usability is not defined. However, these are the basic rules formed over the years of experience of website operators. Application usability generally means: transparency, intelligibility, simplicity. If the e-shop meets these criteria, the customer obtains a better position compared to its competitors.

To understand the buying behaviour of customers, and consequently successful online sales, it is necessary to monitor groups as well as individuals buying certain products. Customer behaviour is dependent on many factors (e.g. social, cultural, personal and psychological) that must be taken into account already in creating e-shop. When compared to the traditional ones, electronic shops have a serious drawback: they are deprived of the involvement of a wider range of the customer's sensory perception. E-shops do not have a possibility to convince the customer to purchase based on smell or touch. For sale on the internet, the most important perception is the visual perception of products, rarely accompanied by sound. All the more emphasis should be placed on the quality of the representation of products, brands and colours so that they affect the buyer in a trustworthy and interesting way.

Just as a number of factors affect the shopping behavior as a whole, so is the actual act of purchase conditioned by many factors, such as family, friends and awareness of the product offered and the ease of purchase on the Internet. In the Internet environment, there are different user groups (Blažková, 2005):

- direct information seekers - looking for information about products, services via web sites, search engines, electronic catalogs,

- indirect information seekers - they spend their free time at the computer clicking on various links and banners,

- direct shoppers - compare products along with prices and then buy the goods chosen,

- bargaining seekers - looking for offers only in the form of discount programs, special offers,

- entertainment seekers - Internet users looking for entertaining games and quizzes. 
However, we consider this division as guidelines only. Many more variants can occur in the buying process. In the past, a very common behaviour was customers visiting a brick-andmortar shop where they had the catalogue presented, found out as much information as possible and heard the retailer's recommendations. However, they bought the goods on the basis of the best-value-for-money offer on the Internet. Lately, however, we have seen a change, and that is the opposite of customer behaviour. Customers first seek information about products on the Internet, especially recommendations and experiences of other users, and then go buy goods in a brick-and-mortar shop. It is also one of the many reasons why major e-commerce operators set up goods issuing offices and even entire brick-and-mortar shops. In them, you can usually buy goods for the same price as on the Internet or with only a slight surcharge for importing them to the shop.

\subsection{Measuring Efficiency}

The advantage of marketing communication on the Internet is the possibility of its relatively easy measurability. Evaluation of the efficiency of marketing communication, i.e. also of various forms of sales promotion, has come to be known as web traffic analysis or web analytics. Analysis of the web site traffic includes both segmenting visitors by access source, device type, geographic, sometimes even demographic and other factors, and an overview of the performance of the e-shop. It also allows you to determine the customer behaviour directly on the website. Traffic analysis serves as a basis for improving the efficiency of web sites (eshop). A precondition for traffic analysis is the implementation of one of the tools for this analysis. In terms of introduction and evaluation, the simplest and most widely used is Google Analytics.

Google Analytics works on the principle of measurement using the active content (JavaScript tracking code). Compared to the analysis based on logs, its advantage is the elimination of entries by robots and accurate identification of visitors using cookies. There is also an option of monitoring the visitors moving in the e-shop. A disadvantage may be the undervaluation of visits and the necessity to set filters before the measurement. With Google Analytics, e-shops can analyze very well the effectiveness of marketing campaigns and, with a careful adjustment and a thorough analysis, even the effectiveness of different forms of sales promotion.

Other tools are used intended rather for large e-shops or websites with high traffic:

- Yahoo! Web Analytics - available only to partners of the Yahoo! Company,

- Omniture - this tool is used by the largest companies, and is intended only for specialists and trained personnel.

Without the traffic analysis, one cannot properly set up various forms of sales promotion, or determine efficiency of other methods of the marketing communications, because the traffic analysis aims to understand what customers want (Clifton, 2009).

\section{Conclusion}

With the development of the Internet, marketing communication on this medium is also growing dynamically and changing. Customers are gradually moving towards online shopping and simultaneously has an e-commerce a huge impact on marketing Sun, 2012). Internet sales are growing significantly, the number of e-shops is increasing, thereby increasing 
competition $^{2,3}$. This gives birth to the need for continuous improvement of communication with customers. Therefore, as a consequence, marketing communication is assuming newer and newer forms, especially in the online environment. Also, the use of mobile devices is changing the view of communication with customers and forms of such communication ${ }^{4}$. Various forms of public relations are coming to the fore, especially with regard to the rapid development of social media among new generation users (Bolton, 2013; Chaffey, 2013). For e-shops, however, these activities are not crucial. Their job is, in marketing communications, to focus mainly on sales promotion, through which website visitors become customers.

According to Rout (2012) brand loyalty is decreasing and therefore must eshops accelerate sales and number of customers by using various forms of sales promotion. On the other hand, too generous sales promotion may cause a number of complications for companies both in terms of reducing sales margins and increasing costs. Customer demand for discounts or free shipping requirements bring these very problems to e-commerce operators. Finding a balanced system is up to each retailer. Analysis of e-shop traffic, customer behaviour during searching for products, analysis of the purchasing process and the overall evaluation of efficiency of different sales promotion forms play an important role in this.

The authors believe that these findings generate sufficient prerequisites for subsequent qualitative and quantitative research aimed at increasing the efficiency of sales promotion in electronic shops.

\section{Acknowledgement}

The authors thank for the financial support provided by the Grant Agency of the Czech Republic under the project No 403/12/1279 "Tools for strengthening the long-term relationships with customers based on integration and cooperation of value network subjects."

\section{References}

[1] BLAŽKOVÁ, M., 2005: Jak využít internet v marketingu. Krok za krokem k vyšší konkurenceschopnosti. $1^{\text {st }}$ Edition. Praha: Grada Publishing. 156 pp. Vysoká škola ekonomická Praha, No. 2219. ISBN 80-247-1095-1

[2] CHAFFEY, D. and P. R. SMITH, 2013. eMarketing eXcellence: Planning and optimizing your digital marketing. Routledge. ISBN 978-0415533379

[3] CLIFTON, B., 2009. Google analytics: podrobný průvodce webovými statistikami. $1^{\text {st }}$ Edition. Translated by Lukáš Krejčí. Brno: Computer Press, 334 pp. ISBN 978-80-2512231-0.

[4] DE PELSMACKER, P., M. GEUENS and J. VAN DEN BERGH, 2003. Marketingová komunikace. Praha: Grada Publishing. 600 pp. ISBN 80-247-0254-1.

[5] FORET, M., 2006. Marketingová komunikace. Brno: Computer Press. 444 pp. ISBN 80-251-1041-9.

\footnotetext{
${ }^{2}$ E-commerce 2012: trendy a názory: Výzkum mezi českými internetovými uživateli. Gemius [online]. [cit. 2013-05-02]. Available from: http://www.ecommerce-studie.cz/

${ }^{3}$ Ecommerce Sales Topped \$1 Trillion for First Time in 2012. EMarketer [online]. 2013. vyd. [cit. 2013-05-02]. Available from: http://www.emarketer.com/Article/Ecommerce-Sales-Topped-1-Trillion-First-Time2012/1009649

${ }^{4}$ Global mobile statistics 2012. MobiThinking [online]. [cit. 2013-05-02]. Available from: http://mobithinking.com/mobile-marketing-tools/latest-mobile-stats/
} 
[6] FREY, P., 2008. Marketingová komunikace. Praha: Management Press. 204 pp. ISBN 978-80-7261-160-7.

[7] HESKOVÁ, M. a P. ŠTARCHOŇ, 2009: Marketingová komunikace a moderní trendy v marketingu. 1. vyd. Praha: Oeconomica. 180 pp. Vysoká škola ekonomická Praha, No. 6-1969. ISBN 978-80-245-1520-5

[8] JANOUCH, V., 2010. Internetový marketing. Brno: Computer Press. 304 pp. ISBN 978-80-251-2795-7.

[9] JANOUCH, V., 2011. Marketingová komunikace na webových stránkách. Pardubice. Dissertation. Univerzita Pardubice.

[10] KOTLER, P. and K. L. KELLER, 2007. Marketing management. $12^{\text {th }}$ Edition. Praha: Grada Publishing. 788 s. ISBN 978-80-247-1359-5.

[11] LAMB, CH. W., J. F HAIR and C. D MCDANIEL, Essentials of marketing. $7^{\text {th }}$ Edition. Mason, Ohio: South-Western Cengage Learning, c2012, xxiii, 648 pp. ISBN 05-3847834-9.

[12] LAMB, CH. W., 2011. Mktg5. $5^{\text {th }}$ Edition. Mason, OH: South-Western, pp. cm. ISBN 978-111-1528-096.

[13] LOŠŤÁKOVÁ, H. et al., 2009. Diferencované řízení vztahů se zákazníky. Praha: Grada Publishing. 268 pp. ISBN 978-80-247-3155-1.

[14] PRIDE, W. M, R. J. HUGHES and J. R KAPOOR. Business. $11^{\text {th }}$ Edition. Mason, OH: South-Western Cengage Learning, c2012, xxxi, 672 pp. ISBN 11-115-2620-6.

[15] SHIMP, T. A. Advertising, promotion, and other aspects of integrated marketing communications. $8^{\text {th }}$ Edition. Mason, Ohio: South-Western Cengage Learning, c2010, xx, 668 pp. ISBN 978-0-324-59360-0.

[16] BOLTON, R. N. et al., 2013. Understanding Generation Y and their use of social media: A review and research agenda. Journal of Service Management, 24.3: 2-2.

[17] ROUT, D. and A. K. JAIN, 2012. THE ROLE OF DIGITAL TECHNOLOGY IN RETAILING. Asian Journal of Business and Economics, 2.2.3.

[18] SUN, J., 2012. Studies on Impact of Electronic Commerce to Modern Marketing Environment. Business and Economic Research, 2.1. 